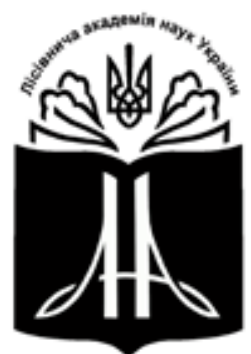

Forestry Academy of Sciences of Ukraine

Наукові праці Лісівничої академії наук України Proceedings of the Forestry Academy of Sciences of Ukraine

http://fasu.nltu.edu.ua https://doi.org/10.15421/411825

Article received 2018.08.19

Article accepted 2018.10.25
ISSN 1991-606X print

ISSN 2616-5015 online

(a) $\triangle$ Correspondence author

Yu. Kahaniak

kaganiak@yahoo.ca

General Chuprynka st., 103, Lviv, 79057, Ukraine

\title{
Еталон лісових насаджень на заповідних територіях Національного природного парку «Сколівські Бескиди»
}

\author{
Ю.Й. Каганяк ${ }^{1}$, М. М. Король ${ }^{2}$, С. А. Гаврилюк ${ }^{3}$, О.Є. Токар ${ }^{4}$, А. М. Цуняк ${ }^{5}$
}

Облік лісових масивів природоохоронних об'єктів є первинним етапом оцінення їх потенціалу. Об 'єктом дослідження є лісові насадження заповідної зони Національного природного парку «Сколівські Бескиди». Метою дослідження передбачено відібрати еталон, тобто лісові насадження із максимальним біорізноманіттям та продуктивністю, складною вертикальною структурою. Методику вибіркової лісової інвентаризації вважають найбільш адекватною для отримання репрезентативних даних. Для таких об'єктів лісівничо-таксаиійна характеристика доповнюється аналізом просторової структури насаджень та оиінкою біорізноманіття.

На території Майданського лісництва виявлено еталон лісових насаджень. Еталон представлений триярусними деревостанами. Після розроблення моделей залежності середнього приросту деревостану від середнього віку, а також запасу деревостану від середнього діаметра дерев першого ярусу, усі об 'єкти розділено на дві групи. До першої групи відібрано об’єкти, котрі за величиною запасу (приросту) потрапляють до верхньої частини довірчої зони моделі з одностороннім обмеженням 1-2 стандартні відхилення.

Відібрано шість еталонів у віковому діапазоні 55-136 років. Яруси лісового насадження складаються із бука лісового, яличі білої та ялини європейської. Один еталон характеризує деревостан з модрини європейської, явора, ялини та ялииі. Частка дерев в першому ярусі змінюється в межах 43-63\%, у другому - 4-32\%, у третьому $-24-31 \%$.

Високопродуктивні структурно складні еталони є типовими природними утвореннями, на котрі повинна орієнтуватися господарська діяльність підприємства.

Ключові слова: мішаний деревостан; структура; тип розміщення дерев; запас; кількість дерев; ярус; біорізноманіття; індекс.

Вступ. Переходу господарювання на принципи використання лісової екосистеми як поліфункціонального об'єкта передує опрацювання відповідної

моделі та нагромадження достатньої верифікованої інформації про структуру, продуктивність, стан лісових комплексів тощо.

Каганяк Юліан Йосипович - член-кореспондент Лісівничої академії наук України, доктор сільськогосподарських наук, професор кафедри лісової таксації та лісовпорядкування. Національний лісотехнічний університет України, вул. генерала Чупринки, 103, м. Львів, 79057, Україна. Тел.: +38-067-587-42-66. E-mail: kaganiak@yahoo.ca

2 Король Микола Михайлович - кандидат сільськогосподарських наук, доцент кафедри лісової таксації та лісовпорядкування. Національний лісотехнічний університет України, вул. генерала Чупринки, 103, м. Львів, 79057, Україна. Тел.: +38-067-670-20-55. E-mail: nikkorol@ukr.net

3 Гаврилюк Сергій Анатолійович - кандидат сільськогосподарських наук, доцент кафедри лісової таксації та лісовпорядкування. Національний лісотехнічний університет України, вул. генерала Чупринки, 103, м. Львів, 79057, Україна. Тел.: +38-068-760-91-99. E-mail: serhiy_havrylyuk@nltu.edu.ua

4 Токар Ольга Євгенівна - кандидат технічних наук, доцент кафедри міжнародної інформації. Національний університет «Львівська політехніка», вул. С. Бандери, 12, м. Львів, 79013, Україна. Тел.: +38-066-270-11-40. E-mail: tokarolya@gmail.com

5 ЦЦуняк Анна Миколаївна - завідувач відділення землевпорядкування та дизайну, екологічний коледж Львівського національного аграрного університету, вул. Замарстинівська, 167, м. Львів, 79068, Україна. Тел.: +38-032-252-10-15. E-mail: anna.tsuniak72@gmail.com 
Просторова й вікова структури, видове різноманіття $є$ важливими характеристиками фітоценозу. Відомо, що структура лісових масивів змінюється множиною чинників. До основних із них зараховують: регіон (географічне розміщення), природний ареал деревних лісотвірних порід, густоту населення й інфраструктуру, інтенсивність ведення лісового господарства.

Вивчення структурної специфіки лісових екосистем допомагає встановити як внутрішні взаємозв'язки між особинами популяції (конкуренцію, симбіоз), так і динаміку розвитку деревостану.

Успішне виконання такого завдання безпосередньо пов'язане із вибором методу обліку. Враховуючи, що об'єкт презентований складними за формою насадженнями на великій площі, переважно рекомендують застосовувати методику вибіркової лісової інвентаризації.

Складні за формою насадження $є$ складнішими і для опису та моделювання. У таких об’єктах потрібно звернути увагу не тільки на диференціацію за окремими таксаційними показниками (діаметром, висотою тощо), а на такі ознаки, як розміщення на площі особин, їх просторове змішування як за породами, так і за віком й розмірами (Atrohin, 1980, Hryhoriev \& Husein, 1985, Kahaniak \& Rehush, 2014, Rehush \& Kahaniak, 2014). Структурно складні об'єкти відрізняються як за закономірністю вертикального заповнення ярусів, так і за особливостями горизонтального скупчення рослин.

Теоретично відомо, що структуру лісостану вичерпно описує розподіл особин за певною ознакою, що інформує зміну атрибутів об'єкта, які визначають його екологічну та економічну цінність (Danchuk, Korol \& Havryliuk, 2007, Delehan \& Korol, 2002, Rehush \& Kahaniak, 2015, Secretenko, 1985).

Початкову адекватну оцінку деревостану можна встановити за двома ознаками: густотою та структурою. Густота $є$ кількісною мірою ступеня заселення деревами площі, а структура - розподілу деревних атрибутів у насадженні.

Вивчення особливостей структури, продуктивності та стану лісових екосистем $є$ вихідною інформацією для розроблення або модифікації підходів формування високопродуктивних деревостанів. Практична реалізація зазначених підходів корелює із вибором та оцінкою із множини тих об'єктів, які можна вважати еталонними.

Актуальність роботи полягає у дослідженні та оцінюванні структури еталонних лісових насаджень, що дасть змогу дослідити процеси, які відбуваються у деревостанах без надмірного антропогенного втручання, порівняти їх із експлуатаційним лісами. Таке порівняння дасть змогу розробити системи лісогосподарських заходів на засадах наближеного до природи лісівництва для підвищення продуктивності та стійкості лісових екосистем.

Методика досліджень. Об'єктом дослідження слугували лісові насадження заповідної зони Національного природного парку «Сколівські Бескиди». Предмет дослідження - структурно складні висо- копродуктивні різновікові деревостани природного походження на заповідних територіях.

Мета дослідження - проаналізувати та оцінити структурні особливості лісових масивів заповідних територій Українських Карпат на прикладі лісового фонду Національного природного парку «Сколівські Бескиди», відібрати еталонні об'єкти.

Просторову структуру та продуктивність мішаних насаджень Сколівських Бескид встановлено за матеріалами пробних площ (кругові, прямокутні) й лісоінвентаризаційними даними лісового фонду НПП «Сколівські Бескиди».

Просторову та вікову структури, запас насаджень заповідної зони визначено на кругових пробних площадках з фіксованою площею $500 \mathrm{M}^{2}$. Метод випадкового відбору площадок дає змогу адекватно оцінити лісові масиви заповідної зони і на підставі комплексних показників охарактеризувати приналежність їх до певних категорій.

Закладання пробних площадок і картування горизонтального розміщення дерев здійснювали з використанням технології «Field-Mар», а їх прив'язку GPS-навігаторм. Матеріали пробних площадок обробляли на ПЕОМ за допомогою програми «Microsoft Excel-2007», «Microsoft Access-2007» та програми R.

Просторову структуру насадження оцінюють комплексно, що передбачає вивчення вертикальної, горизонтальної й вікової структур, а також рясності кожного виду.

Вертикальна структура полягає в поділі насадження на яруси. Теоретичне значення середньої висоти кожного ярусу враховує зв'язок діаметра із висотою дерев. Моделювання рекомендують здійснювати функцією Чапмана-Річардса (Rehush \& Kahaniak, 2015).

Вертикальна структура насадження, або будова за ярусами чи вертикальними горизонтами, вказує на скільки відсотків зайнято рослинністю кожний умовний шар (ярус).

Принципову схему розподілу дерев насадження між ярусами показано на рис. 1 .



Рис. 1. Схема розподілу дерев насадження між ярусами

Горизонтальну структуру насадження вивчали за низкою ознак: різноманіттям розміщення дерев (позиціюванням), різноманіттям за величиною (варіабельністю ознаки), різноманіттям деревних порід (складом). 
Видове різноманіття встановлено на підставі індексу Шеннона, Шеннона-Претча, а також індексу диференціації дерев $(T)$. Формули розрахунку індексів для визначення видового різноманіття наведено у табл. 1.

Різноманіття за величиною $(T)$ розраховано статистичним способом на підставі відношення середньоквадратичного відхилення $(\sigma)$ ознаки до іiі середнього значення $(X)$. На підставі значення диференціації дерев $T$ можна встановити варіабельність ознаки.

Методи аналізу характеру розміщення дерев поділено на два види: картографічний і статистичний. Перший базується на візуальній інтерпретації детальних планів горизонтального розміщення дерев, другий - на методах теорії випадковості та середніх значень.

Розрізняють такі типи розміщення (позиціювання) дерев: випадковий, груповий, рівномірний. Характер горизонтальної структури (розміщення дерев) пропонують встановлювати за методикою Ріплі, за індексом Кларка-Еванса, за індексом Кокса, за допомогою радіальної функції (Secretenko, 1985), за індексом розсіювання та кутовим індексом.

Тип розміщення дерев встановлювлено на основі аналізу величини індексів: йдеться про індекси Ф. Кокса «lc» (Pretzsch, 2001), Кларка-Еванса «R» (Pretzsch, 2001) та його модифікації за Доннеллі (Pretzsch, 2001), кутового індексу «W» (Gadow, 2001).

Таблиия 1

\section{Основні критерії оцінки видового різноманіття лісів}

\begin{tabular}{|c|c|c|}
\hline Індекс & Формула & Значення \\
\hline Шеннона & $H^{\prime}=-\sum_{j=1}^{n} \frac{n_{i}}{N} \ln \left(\frac{n_{i}}{N}\right)$ & - \\
\hline Шеннона-Претча & $A_{\text {rel }}=\frac{\sum_{i=1}^{S} \sum_{j=1}^{Z} p_{i j} \cdot \ln \left(p_{i j}\right)}{\ln (S \cdot Z)} \cdot 100$ & - \\
\hline Рівномірності & $E_{H}=\frac{H}{H_{\max }}, \mathrm{M}_{\mathrm{i}}=\frac{1}{n} \sum_{j=1}^{n} m_{j i}$ & $\begin{array}{c}\mathrm{E}_{\mathrm{H}}=0,00-\text { відсутнє; } 0,25-\text { низьке; } 0,50-\text { середнє; } \\
0,75-\text { високе; } 1.00-\text { дуже високе }\end{array}$ \\
\hline Диференціації дерев & $\mathrm{T}_{\mathrm{i}}=\frac{1}{n} \sum_{j=1}^{n} t_{j i}, \mathrm{~T}_{\mathrm{i}}=\frac{\sigma}{X}$ & $\begin{array}{l}\mathrm{T}_{\mathrm{i}}=0,05-\text { дуже низька; } 0,06-0,15 \text { низька; } 0,15-0,30 \\
\text { середня; 0,31-0,60 висока; більше 0,61 - дуже висока }\end{array}$ \\
\hline
\end{tabular}

Формули розрахунку індексів для визначення типу розміщення дерев наведено у табл. 2 .

Структурний різновид насадження може бути індикатором для оцінення екологічного різноманіття та стабільності екосистеми. Вивчення структури насадження дає змогу оцінити його походження: дуже близьке до природного, посереднє, дуже віддалене від природного.

Результати досліджень. Типовими для регіону Карпат є одновікові, чисті за складом деревостани. Такі насадження $\epsilon$ наслідком розвитку лісової ін- дустрії та інтенсивного використання деревини населенням.

Однак у більш віддалених районах, де слабо розвинена інфраструктура (під'їні шляхи та лісові дороги), а також на заповідних територіях збереглися старовікові лісові масиви й ліси пралісового типу. Це мішані за складом і мінливі за віком буковосмереково-ялицеві, буково-ялицеві, смереково-ялицеві насадження. Для наукових досліджень вони $\epsilon$ найціннішим об'єктом. 3 множини таких об'єктів пропонуємо відібрати еталон.

Основні критерії оцінки характеру розміщення дерев у насадженні

Таблиия 2

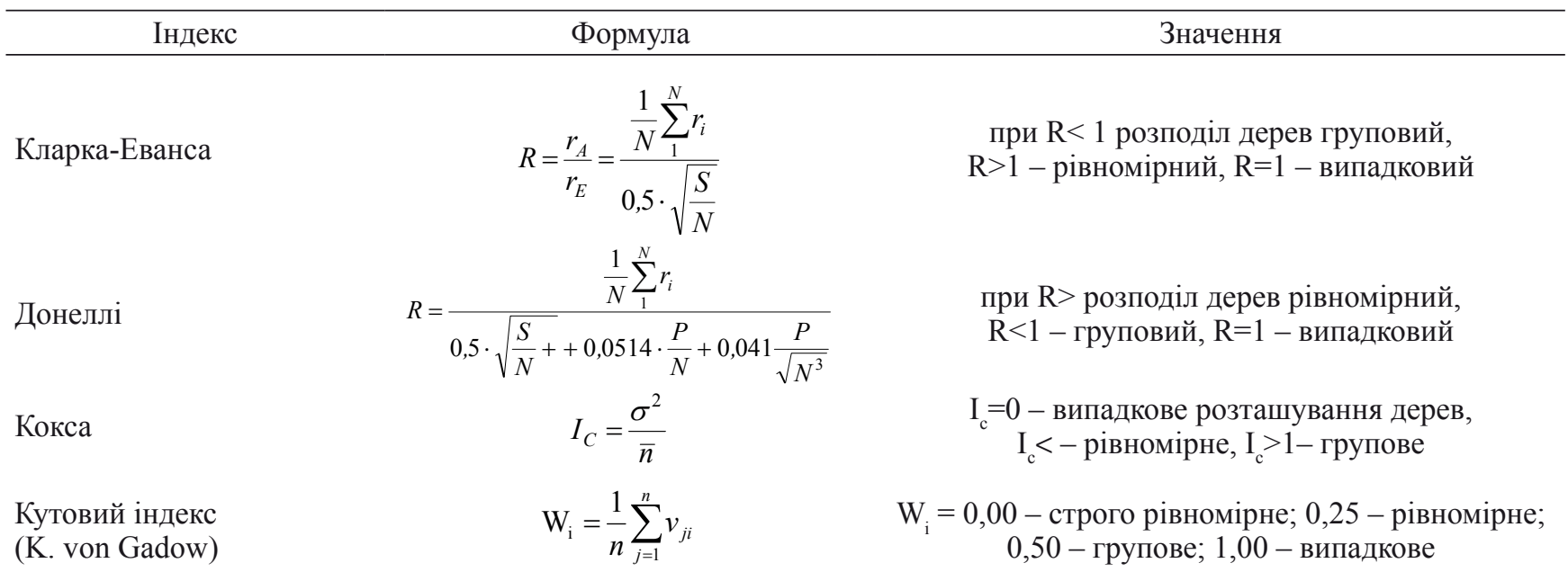


Мішані насадження Сколівських Бескидів зростають на абсолютних висотах 600-1200 м н.р.м. Висота над рівнем моря досліджуваних ділянок змінюється від 650 до 1100 м. Вони переважно охоплюють вологу смереково-ялицеву бучину й субучину, з участю ялиці, ялини, клена-явора. Основними лісотвірними породами $є$ бук лісовий, ялина європейська та ялиця біла. У домішці трапляються клен-явір, в'яз гірський та горобина звичайна.

Заповідна зона НПП «Сколівські Бескиди» об'єднує таксаційні виділи Крушельницького, Майданського, Сколівського, Завадківського та Бутивлянського лісництв. Загальна площа заповідної зони за даними лісоінвентаризації становить 5027,6 га, а запас насаджень - 2271,6 тис. м Найбільша площа заповідної зони розташована у Майданському (46,0\%) та Завадківському $(28,2 \%)$ лісництвах.

Насадження заповідної зони за типом лісорослинних умов локалізовані в $\mathrm{C}_{3}(51,01 \%)$ та $\mathrm{D}_{3}$ $(48,66 \%)$, а фрагментарно - в $\mathrm{C}_{2}(0,15 \%), \mathrm{C}_{4}(0,11 \%)$ та $\mathrm{D}_{4}(0,07 \%)$. Найбільшу частку становлять насадження у вологих гігротопах $(99,6 \%)$. Мізерна частка насаджень $(0,4 \%)$ зосереджена у свіжому й сирому гігротопах.

Треба зазначити, що основну частку лісового фонду заповідної зони становлять насадження I ${ }^{\mathrm{a}}$, I та II бонітетів (97\% від площі); насадження I ${ }^{\mathrm{b}}$ бонітету - лише $0,4 \%$; решту - низькобонітетні насадження (майже $3 \%$ ).

Основну частку площі становлять високоповнотні насадження $(75 \%)$, а низькоповнотні насадження займають тільки $10 \%$ території об'єкта.

Важливою характеристикою $є$ розподіл площі за типом лісорослинних умов та відносною повнотою. Графічну інтерпретацію зазначеного розподілу площі заповідної зони НПП «Сколівські Бескиди» показано на рис. 2. Розподіл площі заповідної зони за типом лісорослинних умов та класом бонітету показано на рис. 3.

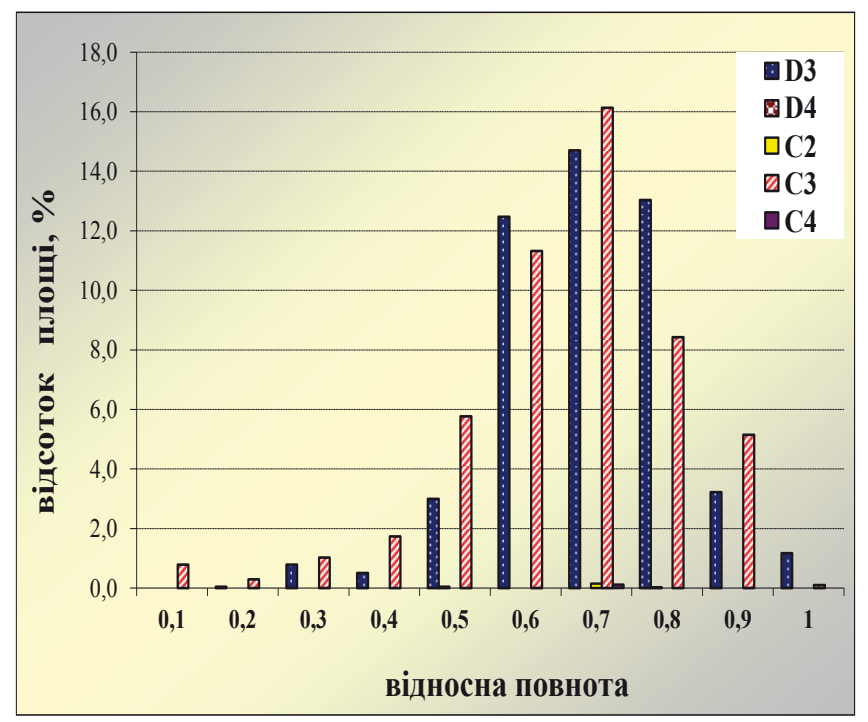

Рис. 2. Розподіл площі заповідної зони НПП за типом лісорослинних умов та відносною повнотою

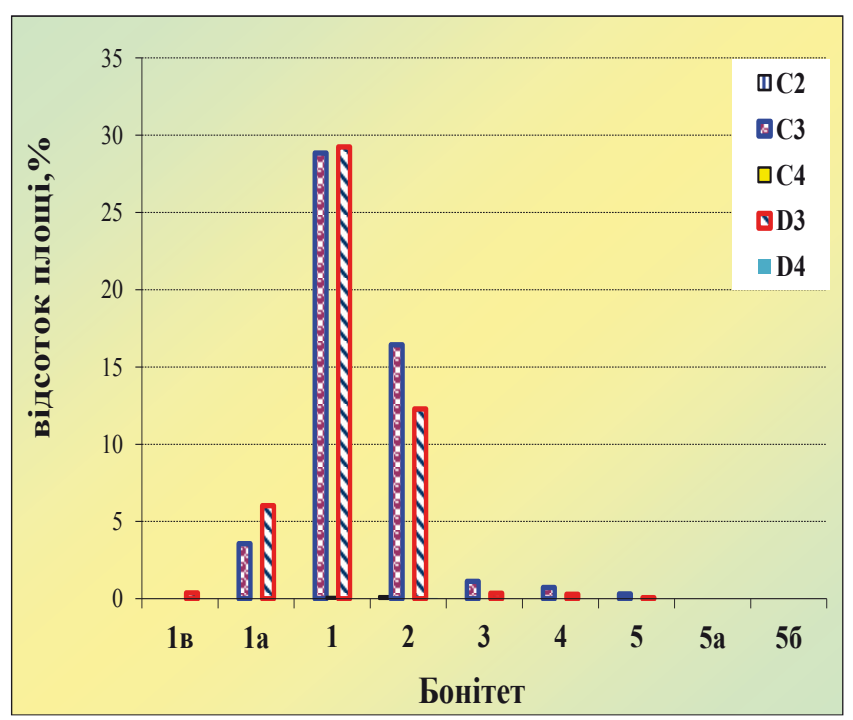

Рис. 3. Розподіл площі заповідної зони НПП за типом лісорослинних умов та класом бонітету

Результати аналізу підтверджують, що модальними $є$ високоповнотні та високобонітетні насадження заповідної зони, які ростуть у свіжому і сирому сугрудах.

Віковий діапазон пробних площ (використаних для відбору еталону) змінюється від 55 до 156 років, відповідно, і кількість дерев приймає значення 220-1200 шт./га. Залежно від повноти та віку насадження їх запас становить від 199 до 1178 м³/га. Максимальні діаметр і висота досягають, відповідно, 88,0 см і 40,5 м, мінімальні - 8,0 см і 8,0 м.

Вікова структура насаджень заповідної зони нерівномірна. Про це свідчить розподіл площі насаджень за класами віку, інформацію про котрий подано в табл. 3.

Наступним важливим показником $є$ загальний запас насадження. Розподіл запасу насаджень за класами віку подано в табл. 4.

Найбільша концентрація запасу для заповідної зони Парку припадає на вік 100 років (858 тис. м або близько $38 \%$ ). Цей клас віку є модальним і при аналізі розподілу площі (34\%).

Вибір еталону лісових насаджень. Аналіз розподілу кількості дерев за ярусами показав значну мінливість. Вибрати еталон з множини об'єктів пропонуємо статистичним методом, шляхом виявлення найпродуктивніших насаджень. 3 цією метою проаналізовано дві залежності: запасу деревостану від середнього діаметра першого ярусу (формула 1: $M=a D^{b}$ ); середнього приросту деревостану від середнього віку (формула 2: $\left.\left.Z=a b c E X P(-b A)(1-E X P(-b A))^{c-1}\right)\right)$. Далі визначають верхню межу теоретичних значень функції, яка тотожна верхній межі довірчої зони. Графічну інтерпретацію залежностей (формули 1-2) показано на рис. 4 i 5 .

Відбір еталонних насаджень здійснено $з$ довірчої зони в межах довірчого коефіцієнта від 1 до 2. На рис. 4 і 5 еталонні насадження позначені точками, які розміщені між двома суцільними лініями. 
Розподіл площі насадження заповідної зони за класами віку

Таблиия 3

\begin{tabular}{cccccc}
\hline Клас віку, років & $\begin{array}{c}\text { Площа } \\
\text { насаджень, га }\end{array}$ & $\begin{array}{c}\text { Площа } \\
\text { насаджень, \% }\end{array}$ & Клас віку, років & $\begin{array}{c}\text { Площа } \\
\text { насаджень, га }\end{array}$ & $\begin{array}{c}\text { Площа } \\
\text { насаджень, \% }\end{array}$ \\
\hline 20 & 61,6 & 1,2 & 140 & 506,7 & 10,1 \\
40 & 191,2 & 3,8 & 160 & 251,8 & 5,0 \\
60 & 436,4 & 8,7 & 180 & 173,7 & 3,5 \\
80 & 939,2 & 18,7 & 200 & 15,5 & 0,3 \\
100 & 1688,1 & 33,6 & 220 & 0,0 & 0,0 \\
120 & 763,4 & 15,2 & 240 & 0,0 & 0,0 \\
- & - & - & Разом & 5027,6 & 100,0 \\
\hline
\end{tabular}

Розподіл запасу насадження заповідної зони за класами віку

\begin{tabular}{cccccc}
\hline \multirow{2}{*}{ Клас віку, років } & $\begin{array}{c}\text { Запас } \\
\text { насаджень, тис. м }\end{array}$ & $\begin{array}{c}\text { Запас } \\
\text { насаджень, \% }\end{array}$ & Клас віку, років & $\begin{array}{c}\text { Запас } \\
\text { насаджень, тис. м }\end{array}$ & $\begin{array}{c}\text { Запас } \\
\text { насаджень, \% }\end{array}$ \\
\hline 20 & 4,6 & 0,2 & 140 & 225,4 & 9,9 \\
40 & 38,9 & 1,7 & 160 & 97,8 & 4,3 \\
60 & 181,3 & 8,0 & 180 & 57,1 & 2,5 \\
80 & 442,8 & 19,5 & 200 & 5,8 & 0,3 \\
100 & 858,0 & 37,8 & 220 & 0,0 & 0,0 \\
120 & 360,1 & 15,9 & 240 & 0,0 & 0,0 \\
- & - & - & Разом & 2271,6 & 100,0 \\
\hline
\end{tabular}

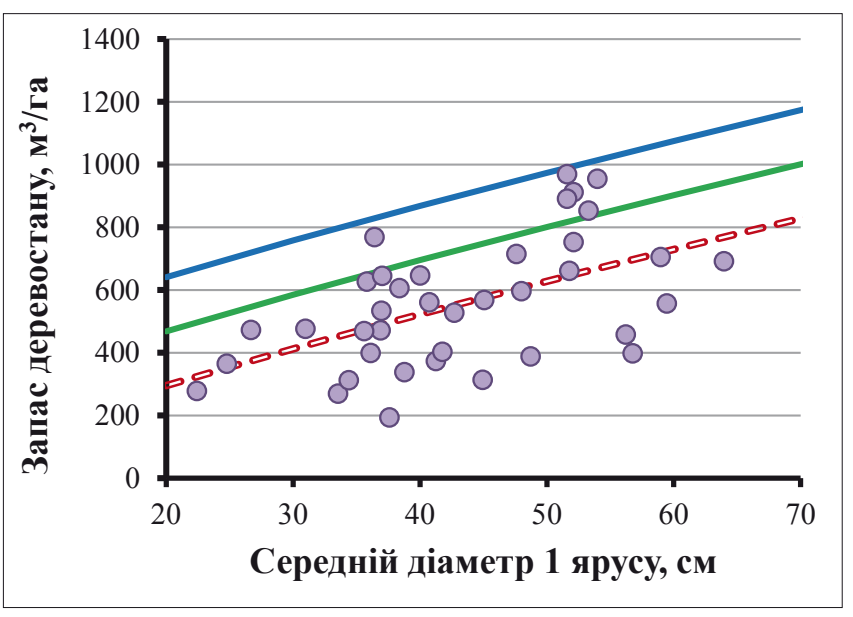

Рис. 4. Залежність запасу деревостану від середнього діаметра першого ярусу

У сітку згущення (растр) потрапили шість пробних площадок із деревостанами в діапазоні віку від 55 до 136 років, які характеризуються найвищими значеннями запасу та середнього приросту деревостанів.

Видову структуру еталону узагальнено і показано в табл. 5.

Перерозподіл кількості дерев та запасу між ярусами у відібраних еталонних насадженнях наведено на рис. 6.

Вертикальна структура $є$ складною i, залежно від історії формування та типу горизонтального розміщення дерев, верхній ярус може становити від 30 до $65 \%$ за кількістю екземплярів. Менша частка

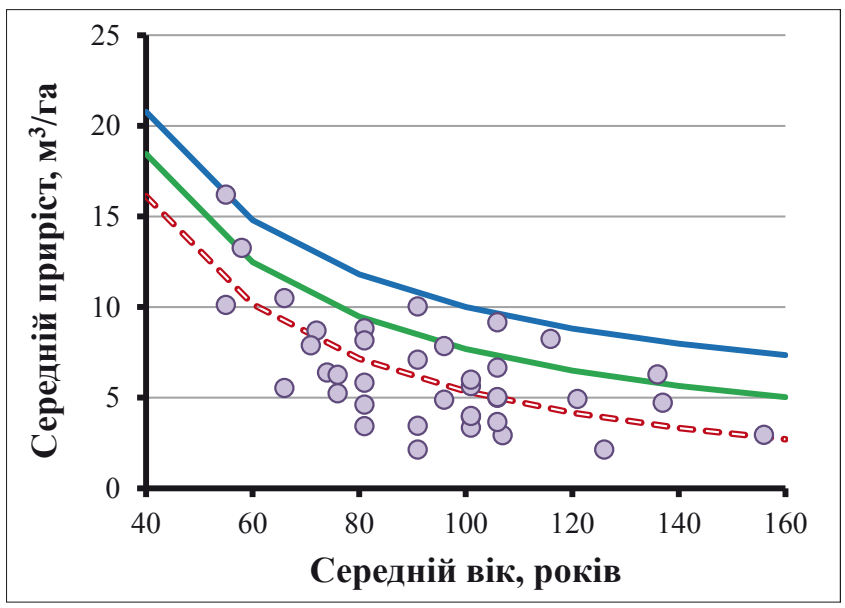

Рис. 5. Залежність середнього приросту деревостану від середнього віку

запасу першого ярусу на пробній площадці Мд_144 корелює із видовим складом. У цьому випадку до складу деревостану, окрім ялиці та смереки, входять явір та модрина.

Очінювання біорізноманіття $і$ характеру розміщення дерев в еталонних лісових насадженнях. Горизонтальне розміщення дерев у насаджені оцінено залежно від величини індексів Шенона $(H)$ та диференціації $(T)$. Індекс Шеннона та індекс диференціації для відібраних еталонів $є$ значним в усіх випадках. Це свідчить про високе видове різноманіття й різновіковість буково-ялицево-ялинових та модриново-яворово-ялинових деревостанів. 
Видова структура еталонних насаджень заповідної зони

\begin{tabular}{ccccc}
\hline Код пробної & \multirow{2}{*}{ Середній вік, років } & \multicolumn{3}{c}{ Видове різноманіття за ярусами } \\
\cline { 3 - 5 } площадки & 55 & Бкл, Яцб & Бкл, Яцб & Бкл, Яцб \\
\hline Мд_145н & 58 & Яв, Мде, См & Яв, Мдє, См, Яцб & Яв, Мдє, Яцб \\
Мд_144 & 91 & Бкл, Яцб & Бкл & Бкл, Яцб \\
Мд_134а & 106 & Бкл, См, Яцб & Бкл, См, Яцб & Бкл, Яцб \\
Мд_91 & 116 & Бкл, См, Яцб & Бкл, См & Бкл \\
Мд_169н & 136 & Бкл, См, Яцб & Бкл, Яцб & Бкл, См \\
Мд_81 & & & & \\
\hline
\end{tabular}

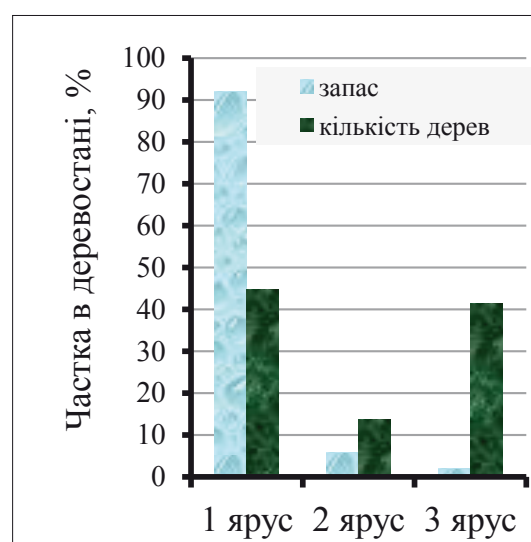

a)

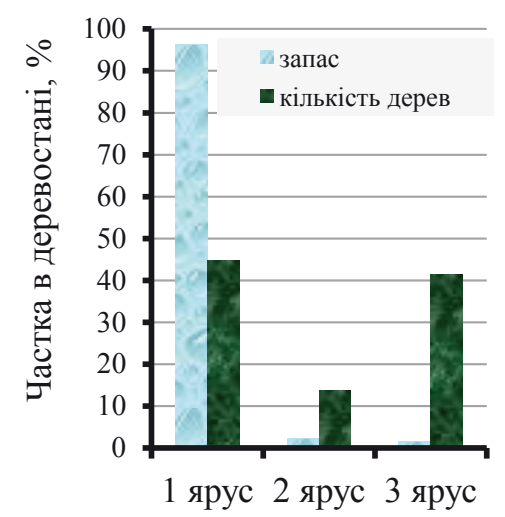

d)

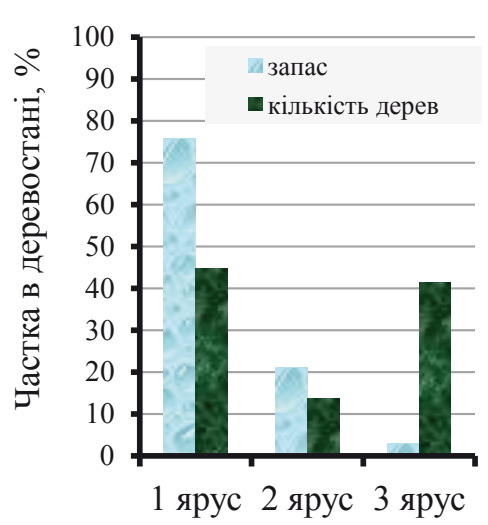

b)

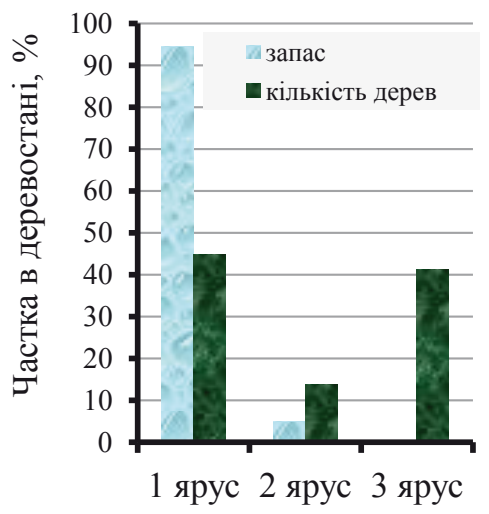

e)

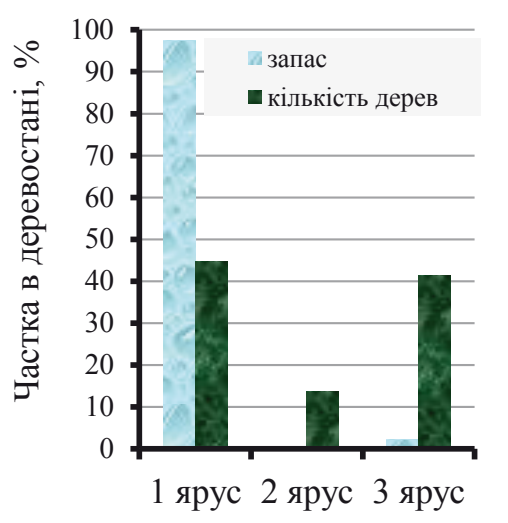

c)

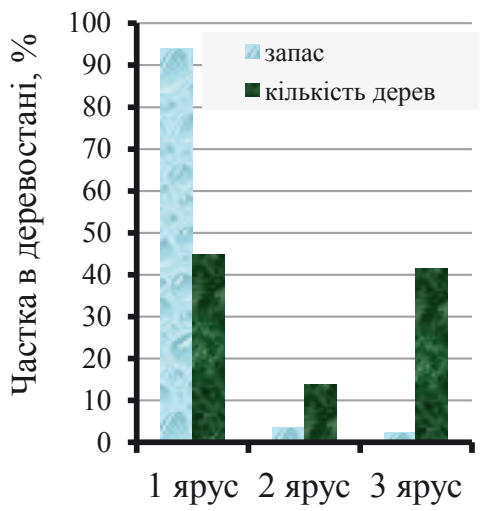

f)

Рис. 6. Диференціація дерев за ярусами еталонних насаджень заповідної зони:

a) на пробній площі Мд_145н; b) на пробній площі Мд_144; с) на пробній площі Мд_134a;

d) на пробній площі М_д_91; е) на пробній площі Мд_169н; f) на пробній площі Мд__81

На території заповідної зони дослідженнями підтверджено збереження природної структури лісових насаджень. Вплив антропогенних чинників тут незначний і взагалі не позначився на якісній та кількісній оцінках лісового насадження.

Для еталонів лісових насаджень оцінено характер просторового розташування дерев. Типи розміщення дерев на пробних площадках наочно проілюстровано на рис. 7.

Для відібраних еталонних мішаних буковоялицево-ялинових деревостанів характерний випадковий, або біогруповий тип розміщення дерев.
Висновки. На підставі аналізу горизонтальної та вертикальної структур, індексів оцінки характеру просторового розташування дерев та видового різноманіття можна стверджувати, що еталон заповідної зони є триярусним складним за будовою, мішаним - за складом лісовим насадженням із переважаючими випадковим та біогруповим типами розміщення дерев.

Вивчення структури насадження дало змогу оцінити його походження, а саме - дуже близьке до природного, посередньо чи дуже віддалене від природного. Еталон деревостанів територіального об'єкта - природного походження. 


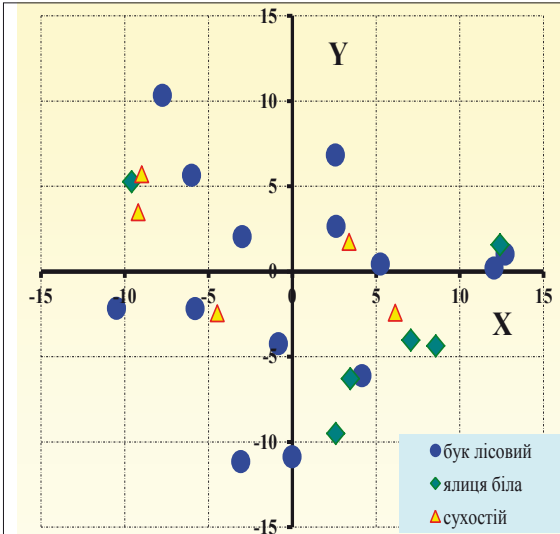

a)

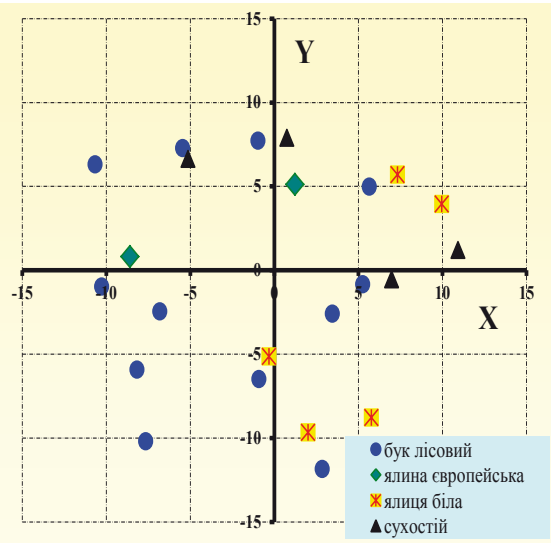

d)



b)

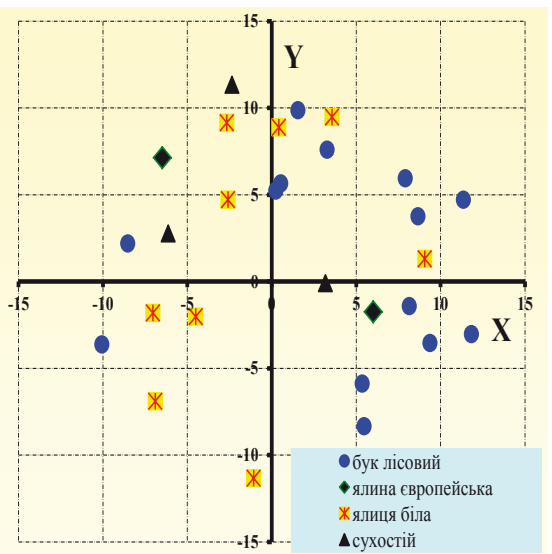

e)

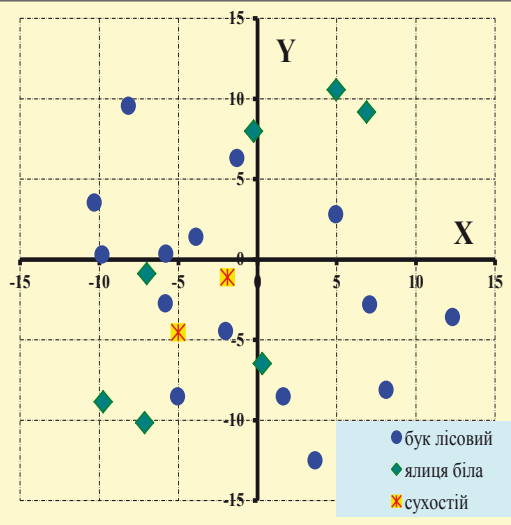

c)

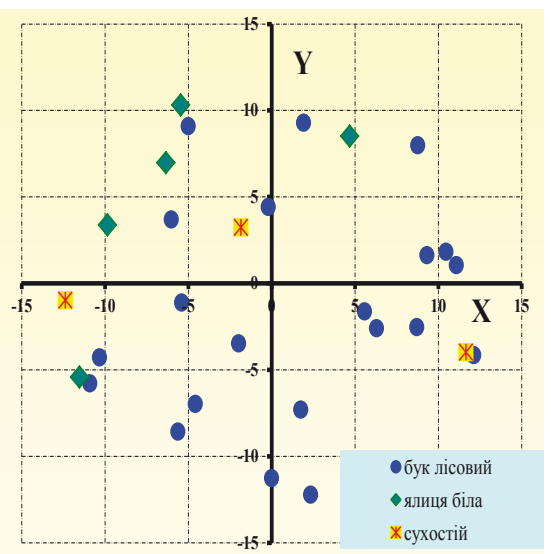

f)

Рис. 7. Горизонтальне розташування дерев у еталонних насадженнях:

a) на пробній площі Мд $145 \mathrm{H} ;$ b) на пробній площі Мд $144 ;$ c) на пробній площі Мд 134a;

d) на пробній площі Мд_91; е) на пробній площі Мд_169н; f) на пробній площі Мд_81

Параметри просторової структури описують як склад насадження, так і гетерогенність габітату (місця існування та проживання). Структурний різновид насадження пропонуємо використати як індикатор для детальнішого оцінення екологічного різноманіття та стабільності екосистеми.

\section{Бібліографічні посилання}

Atrohin, V. (1980). Forming of high productivity stands. Moscow: Forestry industry (in Russian).

Hryhoriev, V. \& Husein, R. (1985). To the question of evaluation of spatial tree location. Silviculture and Forest Management, 20, 62-64 (in Russian).

Danchuk, O., Korol, M., \& Havryliuk, S. (2007). About forest monitoring in NR «Roztochja». Scientific bulletin of the Ukrainian National Forestry University, 17.7, 55-61 (in Ukrainian).

Delehan, I. \& Korol, M. M. (2002). Observation of forest conditions in Europe. Scientific Bulletin of the Ukrainian State Forestry and Wood Working Technologies University, 12.7, 180-168 (in Ukrainian).

Kahaniak, Yu. \& Rehush, N. (2014). Horizontal structure of beech forests of the Transcarpathians.
Proceedings of the Forestry Academy of Sciences of Ukraine, 12, 135-139 (in Ukrainian).

Rehush, N. \& Kahaniak, Yu. (2014). Analysis of beech forest canopies on high resolution satellite images. Scientific bulletin of the Ukrainian National Forestry University, 24.11, 77-83 (in Ukrainian).

Rehush, N. \& Kahaniak, Yu. (2015). Mutual location of trees in the vertical levels of uneven-aged beech stands. Scientific bulletin of the Ukrainian National Forestry University, 25.4, 44-51 (in Ukrainian).

Secretenko O. (1985). Method of analysis of spatial stands structure. Stands structure investigation. Krasnojarsk (in Russian).

Tsuryk, Ye. (2001). Characteristics and mensurational structure of stands. Lviv: Ukrainian State Forestry and Wood Working Technologies University (in Ukrainian).

Gadow v K. (2001) Forest growth. Faculty of Forestry and Forest Ecology in Georg-August-University of Goettingen (in German).

Jaszczak, R. (1999). Monitoring of forests. Poznan: Academy of Agriculture (in Poland).

Keller, M. (Red) (2005). Switzerland National Forestry Inventory. Accessory for fieldwork investigations in 
2004-2007. Birmensdorf: Federal Scientific Institute WSL (in German).

Nagel, J. (1999). Conceptual things for developing of modelling systems for forest growth in North-West Germany. Frankfurt (Oder): Saundlers publisher (in German).

Pretzsch, H. (2001). Forest growth modelling. Berlin: Parey Book Publisher (in German).

Streit, K, Commarmot, B, Temperli, C., \& Brang, P. (2008). Inventory in Natural Reserves of Switzerland: Instruction. Birmensdorf: Federal Scientific Institute WSL (in German).

\section{Эталон лесных насаждений на заповедных территориях Национального природного парка «Сколивские Бескиды»}

\author{
Ю.И. Каганяк ${ }^{1}$, Н. М. Король², С. А Гаврылюк, \\ О.Е. Токар ${ }^{4}$, А.Н. Цуняк ${ }^{5}$
}

Учёт лесных массивов природоохранных объектов является первичным этапом научных исследований, касающихся оценки их ресурсного потенциала и других качеств.

Объектом исследования являются лесные насаждения заповедной зоны Национального природного парка «Сколивские Бескиды». Цель исследования состоит в отборе эталона. Эталоном считается то лесное насаждение, которое характеризируется максимальным биоразнообразием и продуктивностью, наиболее сложной вертикальной структурою.

Каганяк Юлиан Иосифович - член-корреспондент Лесной академии наук Украины, доктор сельскохозяйственных наук, профессор кафедры лесной таксации и лесоустройства. Национальный лесотехнический университет Украины, ул. генерала Чупринки, 103, г. Львов, 79057, Украина. Тел.: +38-067-587-4266. E-mail:kaganiak@yahoo.ca

Король Николай Михайлович - кандидат сельскохозяйственных наук, доцент кафедры лесной таксации и лесоустройства. Национальный лесотехнический университет Украины, ул. генерала Чупринки, 103, г. Львов, 79057, Украина. Тел.: +38-067670-20-55. E-mail: nikkorol@ukr.net

Гаврилюк Сергей Анатольевич - кандидат сельскохозяйственных наук, доцент кафедры лесной таксации и лесоустройства. Национальный лесотехнический университет Украины, ул. генерала Чупринки, 103, г. Львов, 79057, Украина. Тел.: +38-068760-91-99. E-mail: serhiy_havrylyuk@nltu.edu.ua

4 Токар Ольга Евгеньевна - кандидат технических наук, доцент кафедры международной информации. Национальный университет «Львовская политехника», ул. С. Бандеры, 12, г. Львов, 79013, Украина. Тел.: +38-066-270-11-40. E-mail: tokarolya@, gmail.com

Цуняк Анна Николаевна - заведующая отделением землеустройства и дизайна, экологический колледж Львовского национального аграрного университета, ул. Замарстынивская, 167, г. Львов, 79068, Украина. Тел.: +38-032-252-10-15. E-mail: anna.cunyak.72@mail.ru
Выборочная лесная инвентаризация считается наиболее адекватной методикой, которая дает возможность получить репрезентативные первичные данные об объекте. Специфические особен-ности методологии предусматривают дополнение лесоводственно-таксационной характеристики объекта анализом пространственной структуры лесных насаждений, оценками характера горизонтального размещения деревьев и биоразнообразия.

В результате реализации программы исследований по выборочной инвентаризации и анализа полученных первичных данных, эталоны лесных насаждений найдены на территории Майданского лесничества.

Отобрано шесть эталонов насаждений в возрастном диапазоне от 55 и до 136 лет. Эталон лесных насаждений выбран из множества первичных данных. Для объективного отбора данных дополнительно разработаны две модели. Первая модель описывает зависимость среднего прироста древостоя от среднего возраста. Вторая модель показывает теоретическую зависимость запаса древостоя от среднего диаметра деревьев первого яруса. Далее первичные данные разделены на две группы, учитывая величину критерия (прироста, запаса). Первую группу представляют эталонные лесные насаждения. Эти объекты по величине запаса (прироста) попадают в верхнюю часть доверительной зоны модели с односторонним ограничением 1-2 стандартных отклонения.

Результаты анализа указывает на сложную вертикальную структуру эталона. Деревья эталона распределены между тремя ярусами в различной пропорции. Долевое участие деревьев в первом ярусе колеблется в промежутке 43-63\%, во втором 4-32\%, в третьем - 24-31\%. По результатам анализа распределения запаса установлена наибольшая концентрация в первом ярусе (76-97\%). Максимальное долевое участие запаса во втором ярусе эталона составляет $21 \%$, а в третьем ярусе - 3\%. Ярус эталонного лесного насаждения формируют бук лесной, пихта белая и ель европейская. Единственным эталоном характеризуется лесное насаждение, в состав которого вошли лиственница европейская, клён-явор, ель европейская и пихта белая.

Высокопроизводительные структурно сложные эталоны являются типическими естественными образованиями, на которые должна ориентироваться хозяйственная деятельность предприятия.

Ключевые слова: смешанное насаждение; структура; тип размещения деревьев; запас; количество деревьев; ярус; биоразнообразие; индекс. 


\section{Model forest stands on forest reserve lands of National Nature Park "Skolivski Beskydy»}

\author{
Yu. Kahaniak' , M. Korol'2, S. Havryliuk'3 , O. Tokar', \\ A. Cunjak ${ }^{5}$
}

Accounting of forest fund on forest reserve lands is a primary stage of scientific studies investigations, which are focused on concerning of their resource potential and others qualities.

The study object of investigation is forest stands of reserve zone of the National Nature Park «Skolivski Beskydy». The aim of research is selection of model forest stands. The model forest stands is forest stand with maximum of biodiversity and productivity with most compound vertical structure.

Point cruising inventory is most adequate method for receiving primary data about object of research.

Yulian Kahaniak - Corresponding Member of the Forestry Academy of Sciences of Ukraine, Doctor of Agricultural Sciences, Professor of the Forest Inventory and Management Department. Ukrainian National Forestry University. Hen. Chuprynka str., 103, Lviv, 79057, Ukraine. Tel.: +38-067-587-42-66. E-mail: kaganiak@yahoo.ca

2 Mykola Korol - PhD of Agricultural Science, Associate Professor of the Forest Inventory and Management Department. Ukrainian National Forestry University. Hen. Chuprynka str., 103, Lviv, 79057, Ukraine. Tel.: +38-097-670-20-55. E-mail: nikkorol@ukr.net

Serhii Havryliuk - PhD of Agricultural Science, Associate Professor of the Forest Inventory and Management Department. Ukrainian National Forestry University. Hen. Chuprynka str., 103, Lviv, 79057, Ukraine. Tel.: +38-068-760-91-99. E-mail: serhiy_ havrylyuk@nltu.edu.ua

4 Olha Tokar - PhD of Engineering Science, Associate Professor of the Department of International Information. Lviv Polytechnic National University. Bandera str., 12, Lviv, 79013, Ukraine. Tel.: +38-066-270-11-40. E-mail: tokarolya@gmail.com

Anna Cunjak - Chief of Department of Land Use and Design, Ecological College of Lviv National Agricultural University. Zamarstynivska st., 167, Lviv, 79068, Ukraine. Tel.: +38-032-25210-15. E-mail: anna.cunyak.72@mail.ru
The distinctive feature of this method is providing supplement of silviculturale and inventory indexes of investigated object through by analysis of spatial structure of forest stands, indexes of horizontal tree placement and biodiversity.

The model forest stands in the condition of Majdan forest district were distinguished as a result of point cruising inventory and analyzing of primary data. There were distinguished six model forest stands were distinguished with age range from 55 to 136 years. These models stands were selecting from great number of primary data set. For the objective data selection additionally were developing two patterns were developed. First pattern is in describing dependence between average stand increasing and age. Second pattern is in showing the theoretical dependence of stem volume and average diameter of first stage of stand. The primary data were divided for two groups according to the value (increasing, stem volume). The first group is presented by model forest stands. These objects are laying on the top part of confidence part of model with one-two standard deviation limits.

The analysis is shows complex vertical structure of model stands. The trees of models are distributed between three stand stages in different proportions. The share portions of first stage are varying between 43$63 \%$, second stage $-4-32 \%$ and third $-24-31 \%$. The analysis of volume distribution are showing the largest concentration on first stage (76-97\%). The maximum part of stand volume on the second stage is made $21 \%$ and on third stage $-3 \%$. The stages of model stand are formed from beech, fir and spruce. Only one stand from model stands is characterized by the larch, sycamore, spruce and fir in tree composition.

The high productivity and structural compound model stands are typical nature formations and forest management activity must be oriented at for these stands.

Key words: mixed stand, structure; type of trees placement; stand volume; quantity of trees; stage; biodiversity; index. 